
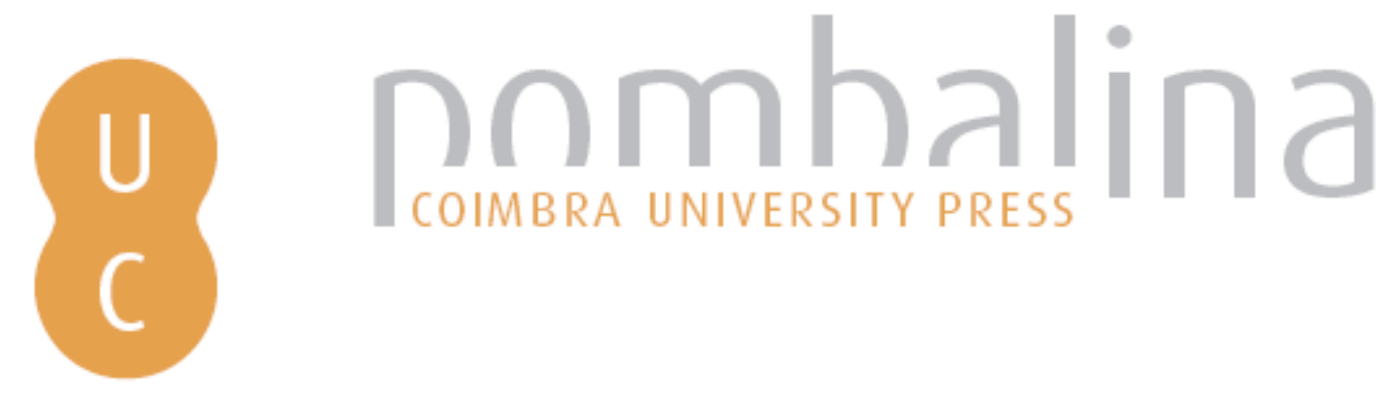

\title{
Time perspective, meaning in life and subjective well-being in macedonian undergraduate students
}

Autor(es): $\quad$ Shterjovska, Marija; Achkovska-Leshkovska, Elena

Publicado por: Imprensa da Universidade de Coimbra

URL

persistente: URI:http://hdl.handle.net/10316.2/38617

DOI: $\quad$ DOI:http://dx.doi.org/10.14195/978-989-26-0775-7_

Accessed : $\quad$ 26-Apr-2023 12:19:02

A navegação consulta e descarregamento dos títulos inseridos nas Bibliotecas Digitais UC Digitalis, UC Pombalina e UC Impactum, pressupõem a aceitação plena e sem reservas dos Termos e Condições de Uso destas Bibliotecas Digitais, disponíveis em https://digitalis.uc.pt/pt-pt/termos.

Conforme exposto nos referidos Termos e Condições de Uso, o descarregamento de títulos de acesso restrito requer uma licença válida de autorização devendo o utilizador aceder ao(s) documento(s) a partir de um endereço de IP da instituição detentora da supramencionada licença.

Ao utilizador é apenas permitido o descarregamento para uso pessoal, pelo que o emprego do(s) título(s) descarregado(s) para outro fim, designadamente comercial, carece de autorização do respetivo autor ou editor da obra.

Na medida em que todas as obras da UC Digitalis se encontram protegidas pelo Código do Direito de Autor e Direitos Conexos e demais legislação aplicável, toda a cópia, parcial ou total, deste documento, nos casos em que é legalmente admitida, deverá conter ou fazer-se acompanhar por este aviso.

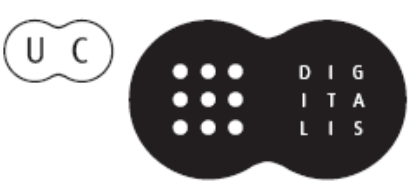




\section{INTERNATIONAL \\ STUDIES IN TIME \\ PERSPECTIVE}

MARIA PAULA PAIXÃO

JOSÉ TOMÁS DA SILVA

(COORD.)

VICTOR ORTUÑO

PEDRO CORDEIRO

(EDITORS)

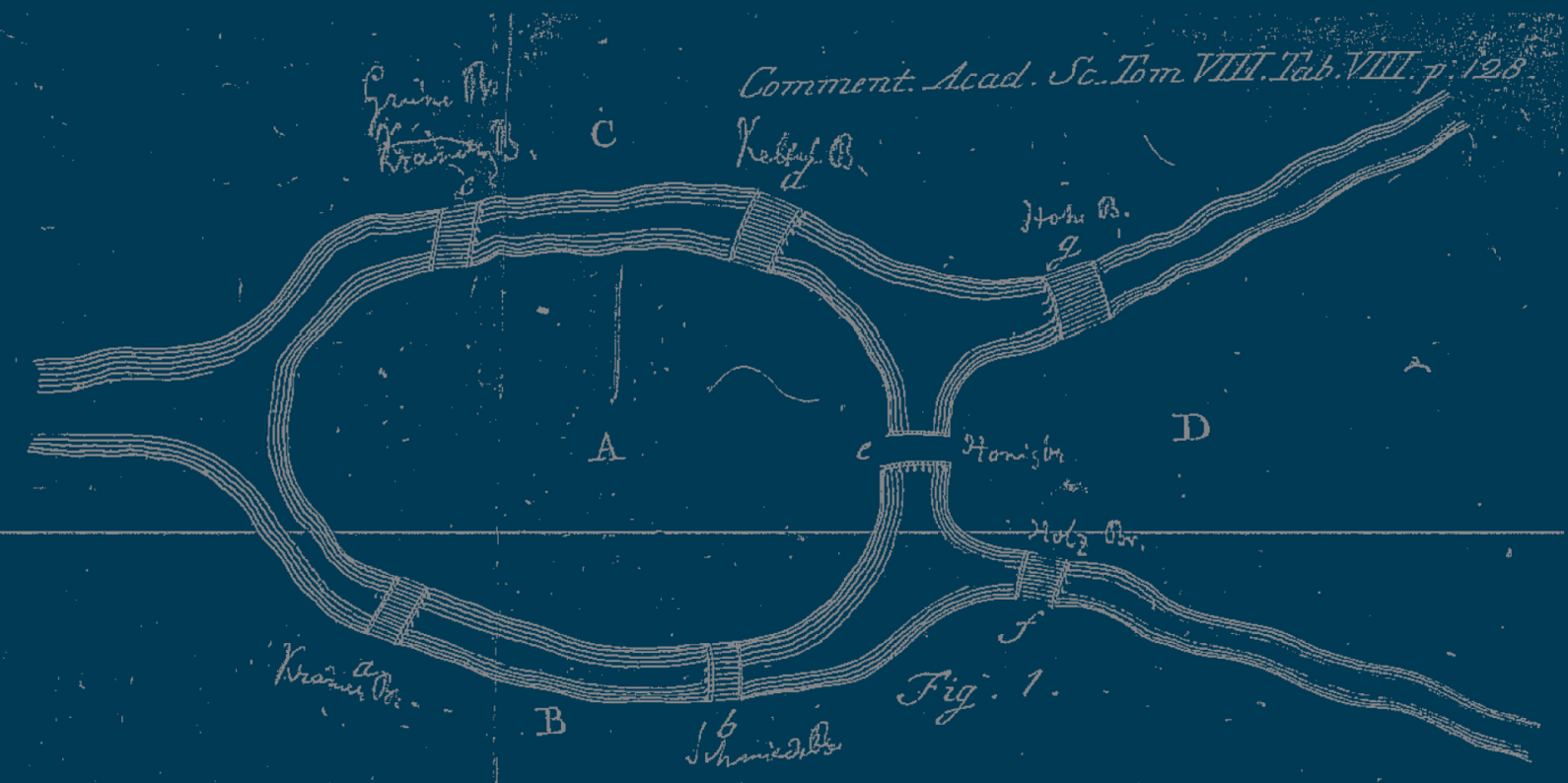

IMPRENSA DA

UNIVERSIDADE

DE COIMBRA

COIMBRA

UNIVERSITY

PRESS 
Chapter 13

Time Perspective, meaning in life and subjective Well-being in MaCEDONian UNDERgRaduATE STUDENTS

\author{
Marija Shterjovska \\ Elena Achkovska-Leshkovska \\ Faculty of Philosophy, Ss. Cyril and Methodius University, Republic of Macedonia \\ stermar86@gmail.com \\ eleskovska@yahoo.com
}

\begin{abstract}
Aвstract: According to previous studies, there is strong relationship between some factors of Zimbardo's time perspective model and well-being, between meaning in life and well-being, as well as between time perspective and meaning in life. Having in mind that similar research haven't been conveyed so far in Republic of Macedonia, the goal of this study was to test inter-correlations among mentioned variables and to explore whether time perspective and meaning in life are significant predictors of the subjective well-being. Participants were undergraduate psychology students from University "Ss Cyril and Methodius" in Skopje. They have completed surveys that assessed time perspective (ZTPI), meaning in life (MLQ) and subjective well-being (PANAS and SWLS). The results have shown that subjective well-being is associated with presence of meaning in life, orientation toward present pleasure (PH), sentimental attitude toward the past (PP) and lack of negative view of the past (PN). Furthermore PH and PP appeared important for presence of meaning in life, while future orientation was associated with search of meaning in life. Finally, it was found that presence of meaning in life and Past-Negative factor significantly predict students' subjective well-being. Overall, the evidence indicates that most of the previous findings are valid for Macedonian context as well.
\end{abstract}

Keywords: time perspective, meaning in life, subjective well-being.

\title{
INTRODUCTION
}

Well-being is a core topic of research in the positive psychology because it deals with many aspects of psychological health as an eternal desirable state of every human being. The most representative ingredients of psychological well-being are happy feelings brought on by something we enjoy and the feeling that what we are doing with our lives has some meaning and purpose. The first, more hedonic facet, refers to Subjective Well-being (SWB) as "person's cognitive and affective evaluations of his or her life" (Diener, Lucas \& Oshi, 2002, p.63). There appear to be at least three major components to subjective well-being: pleasant emotions and moods, lack of negative emotions and moods and satisfaction judgments about one's life. The second facet, the eudemonic one, refers to the extent to which people comprehend, make sense of, or see significance in their lives, accompanied by the degree to which they perceives themselves to have a purpose, mission, or over-arching aim in life (Steger, 2009) 
Beside Presence of Meaning in Life (PML), Search of Meaning in Life (SML) is another crucial dimension that is especially relevant for the adolescents. As they search for meaning both within themselves as well as in the outside world, they are trying to set themselves on a path towards happiness and a full enjoyment of life. During their transition to adulthood, adolescents are facing wide range of difficulties, challenges and changes. In order to encourage a smooth transition it is important to determine their psychological well-being.

Additionally, adolescents are comprised of who they were as children, who they are now and who they wish to become (De Lazzari, 2000). This cognitive operation that implies both an emotional reaction to imagined time zones and a preference for a locating action in past, present or future is named time perspective. The time perspective construct, developed by Zimbardo \& Boyd (1999), consist of five factors, which promotes different attitudes toward temporal frames. Orientation toward past could be positive or negative. PastPositive (PP) reflects a warm, pleasurable, often sentimental and nostalgic view of one's past with maintaining relationships with family and friends. Past-Negative (PN) is characterized by personal experiences that were aversive, traumatic or unpleasant. Orientation toward present could be hedonistic or fatalistic. Present-Hedonistic (PH) refers to living in the moment, in the here and now, pleasure seeking, enjoying high intensity activities, seeking thrills and new sensations and openness to adventures. Present-Fatalistic (PF) is associated with helplessness, hopelessness and a belief that outside forces control one's life, for e.g. spiritual or governmental forces. Finally, Future orientation (F) is concerned with working for future goals and rewards, often at the expense of present enjoyment, delaying gratification and avoiding time-wasting temptations.

Time perspective can become a relatively stable personality trait when a particular temporal bias predominate one's outlook and behavior. When people frequently exhibit one dominant temporal orientation, they may become dysfunctional (Boniwell, 2005). Thus, Zimbardo \& Boyd (1999) promoted the ideal of "balanced TP"(BTP) as optimal for individual psychological health and social functioning. It is defined as the mental ability to switch flexibly among different TP factors depending on situational conditions.

\section{Previous research}

Investigating correlates of well-being and time perspective factors, Drake et al. (2008) reported positive correlations between subjective happiness and $\mathrm{PP}$, as well as $\mathrm{PH}$. On the other hand, subjective happiness was negatively correlated to PN. Surprisingly, there was no significant correlation between happiness and F. Boniwell (2005) reported various studies with non-consistent results regarding association between well-being and some factors of time perspective, except the consistent positive correlation with PP and the negative one with PN.

Well-being is often put in relationship with another construct of positive psychology - presence of meaning in life. According to many studies, they are in strong positive relationship (Reker, Peacock \& Wong, 1987; De Lazzari, 2000; Cairns, 2010). Also the other dimension of the meaning in life, search for meaning in life, appeared to have significant correlation with well-being, but the findings are not consistent about the direction of this relation. Search for meaning in life is in positive relationship with variables that refer to psychological distress such as anxiety, depression, negative affect, neuroticism 
etc. (Steger et. al. 2006). This dimension is differently associated to well-being across the human life span (Steger, Oishi, \& Kashdan, 2009). Searching for meaning in life is more strongly associated with well-being deficits in later life stages, while in adolescence it is adaptive and therefore might be unrelated to well-being. Even more, in another recent study it was concluded that SML has moderating role in positive correlation between PML and satisfaction in life (Steger, Oishi \& Kesebir, 2011).

Time perspective was also significantly correlated to dimensions of meaning in life. Steger et. al. (2008) found positive connection between PML and certain factors of time perspective such as PP, F and PH, as well as negative with PN. Positive correlation was also detected between SML and the factors PN, F and PF (Zimbardo \& Boyd; 1999; Steger et. al., 2008).

\section{Well-being in Macedonian context}

According to Rank Report within World Database of Happiness (Veenhoven, worlddatabaseofhappiness.eur.nl), Macedonian general population sample score 4.7 on scale 0 to 10 regarding how much people enjoy their life-as-a-whole. This report is made on the basis of surveys implemented in 149 nations during the period 2000-2009. Compared with others ex-communist developing countries in the region, who shared similar experiences in the period of transition toward democratic society, average happiness of Macedonian population is slightly higher only from Bulgarians and Albanians. This relatively low rank is understandable having in mind the high rate of unemployment, as well as some others factors that reveal heritage of unpleasant past experiences on a collective level.

Unfortunately, there is very few research regarding well-being and related concepts conducted in the Republic of Macedonia. One recent study (Spasovski, 2009) aimed to explore the relation between subjective well-being, basic psychological needs (BPN), intrinsic and extrinsic life goals (LG), and orientation toward collectivism among undergraduate students. Results show that all BPNs, intrinsic and extrinsic LGs significantly correlated with SWB. Moreover, realization of extrinsic goal, for status/fame, contrary to intrinsic one, appeared to be significant predictor of SWB. According to the author, findings suggest that probably the realization of extrinsic goals has a complementary role to the achievement of intrinsic goals in satisfying one's basic needs and increase of SWB. Additionally, it is found that SWB is positively related with the orientation toward collectivism, that imply the importance of more positive and less negative life experiences with family and friends.

\section{Present study}

The previous findings illuminate a small part of the SWB issue in Macedonian cultural context, but it is far from giving the whole picture. In order to enrich this research field, and to give pioneer contribution to national psychological science, we introduce investigation of time perspective and meaning in life with adolescents as participants. The aim of this study was to examine how factors of time perspective and dimensions of meaning in life are connected to subjective well-being as well as which of the mentioned variables, if any, 
can predict subjective well-being. Also, we were interested whether there is relationship between factors of time perspectives and dimensions of meaning in life.

According to the literature review of theoretical and researching studies on these topics (Drake et al.,2008; Zimbardo \& Boyd,1999; Steger et. al. 2008; Reker, et al., 1987; De Lazzari, 2000; Cairns, 2010) it was hypothesized that SWB would be positively correlated with PML, PP, PH and F time perspective, while negatively correlated with SML, PN and PF. Furthermore, PML was assumed to correlate positively with PP, PH and F, while negatively with PN. SML was hypothesized to be in positive correlation with PN, PF and F. Finally, based on the previous findings (Boniwell, 2005; Steger, et al., 2011) it was proposed that PP, PN and PML would be predictors of SWB.

\section{Method}

\section{Participants and Instruments}

The data for this study were collected in the winter of 2012. We tested 81 female students from the Department of Psychology in the oldest university in the Republic of Macedonia. Participants of this study were 18 to 22 years old with age average of 19.2. They were given a questionnaire booklet contained the following instruments:

ZTPI - Zimbardo Time Perspective Inventory, (Zimbardo \& Boyd, 1999). The 56-item scale consists of 5 subscales measuring 5 factors of time perspective: Past Positive, Past Negative, Present Hedonistic, Present Fatalistic and Future.

MLQ - Meaning in Life Questionnaire, (Steger et al., 2006). This 7-point Likert scale consists of 10 items assessing 2 dimensions: Presence of Meaning in Life and Search for Meaning in Life.

PANAS - Positive and Negative Affect Schedule, (Watson \& Clark, 1988). The scale consists of 20 items, 10 related to positive affects (PA) and 10 to negative affects (NA).

SWLS - Satisfaction with Life Scale, (Diener et al., 1985). This 7-point Likert scale consists of 5 items assessing global judgment of satisfaction with life.

Numerous studies have demonstrated high reliabilities for the mentioned scales in many different cultures. The first two scales are for the first time used in Macedonian context, so their reliability was tested. In the Macedonian sample Cronbach's alphas for ZTPI subscales were: .55 for Past Positive, .71 for Past Negative and for Hedonistic Present, .62 for Fatalistic Present and .74 for Future. The current sample alphas for MLQ subscales were: .72 for Presence of Meaning in Life and .83 for Search for Meaning in Life.

The last two scales are used to measure the construct subjective well-being which is combination of cognitive and affective dimensions (Diener, Lucas \& Oshi, 2002). The variables that determine subjective well-being were transformed into standardized scores $(z$ scores) before calculating subjective well-being with the following formula: SWB = SWLS $+(\mathrm{PA}-\mathrm{NA})$.

\section{Results AND Discussion}

Table 1 provides a summary of the correlations, means and standard deviations for all of the measured variables. It is obvious that subjective well-being is significantly associated 
with the following variables: PML ( $\mathrm{r}=.309, \mathrm{p}<.01)$, PH ( $\mathrm{r}=206, \mathrm{p}<.05), \mathrm{PP}(\mathrm{r}=.259, \mathrm{p}<.01)$ and $\mathrm{PN}(\mathrm{r}=.-.391, \mathrm{p}<.01)$. Furthermore, PML has positive correlation with $\mathrm{PH}(\mathrm{r}=.272$, $\mathrm{p}<.01)$ and with PP $(\mathrm{r}=.211, \mathrm{p}<.05)$. Finally, SML is positively related to $\mathrm{PN}(\mathrm{r}=.222$, $\mathrm{p}<.05)$ and to $\mathrm{F}(\mathrm{r}=.325, \mathrm{p}<.01)$.

Table 1 - Correlations, Means and Standard Deviations for Subjective Well-Being,

Time Perspective Factors and Meaning in Life Dimensions $(N=81)$

\begin{tabular}{|l|c|c|c|c|c|c|c|c|}
\hline \multicolumn{1}{|c|}{ Scales } & PP & PN & PH & PF & F & PML & SML & SWB \\
\hline PP & - & $-.187^{*}$ & $.209^{*}$ & .032 & $.326^{* *}$ & $.211^{*}$ & .154 & $.259^{* *}$ \\
\hline PN & & - & $-.203^{*}$ & $.314^{* *}$ & .167 & -.154 & $.222^{*}$ & $-.391^{* *}$ \\
\hline PH & & & - & $.211^{*}$ & $-.286^{* *}$ & $.272^{* *}$ & -.037 & $.206^{*}$ \\
\hline PF & & & & - & -.026 & -.089 & .124 & -.099 \\
\hline F & & & & & - & .170 & $.325^{* *}$ & -.056 \\
\hline PML & & & & & & - & -.040 & $.309^{* *}$ \\
\hline SML & & & & & & & - & -.046 \\
\hline SWB & & & & & & & & - \\
\hline M & 3.62 & 2.84 & 3.72 & 3.14 & 3.47 & 26.28 & 25.48 & -.04 \\
\hline SD & .46 & .58 & .42 & .51 & .50 & 5.08 & 6.21 & 1.59 \\
\hline
\end{tabular}

${ }^{*} \mathrm{p}<.05 .{ }^{* *} \mathrm{p}<.01$

These results confirm the thesis that people need an important tool to give meaning to their lives and control it, and that tool is time (Eryllmaz, 2011). The subjective judgment of individual well-being depends on temporal orientation. As Durayappah (2011, p.30) points out in his 3P Model, "SWB is a temporal component, for we not only desire to pursue happiness (Prospect), but also to experience it (Present), as well as protect our previously acquired happiness (Past)". We measure our SWB in each temporal state based on the pleasure derived from expecting, experiencing or evaluating and therefore our preferences toward a certain state influenced our overall SWB.

According to the findings in our study, SWB of Macedonian female undergraduates is mainly derived from pleasurable views of previous interpersonal relationships with family and friends and capability to avoid anxieties and depressive thoughts and feelings. One possible interpretation of the results is the fact that Republic of Macedonia was excommunist country and before its independency, 20 years ago, it was part of the Yugoslav Federation. Within the Federation, popular slogan was "brotherhood and unity" and it determined collectivistic orientation as one of the core values. It might be beneficial to be a collectivist in a collectivistic country because patterns of relations with the important others create more positive and less negative life experiences. Although nowadays young generations are more and more influenced by Western individualistic lifestyle (i.e. competitive and individual focused), yet collectivistic tradition of their parents is not easily replaceable. 
Positive significant correlation between SWB and PH confirmed the expectation that adolescents' judgment of their satisfaction with life is due to the great pleasure they obtained from ongoing adventures of the moment, highly intense activities and excitements found in the here and now. There are several reasons that might explain this relation. First of all, hedonism is more typical for adolescents than for adults. Furthermore, as Boniwell (2005) stated, people living in southern areas and those with collectivistic orientation tend to be more present-oriented. Those characteristics are representative for inhabitants in our country, too. Additionally, the lack of optimistic view for future opportunities in Macedonian setting, make adolescents compensate it with daily enjoyment and activities that bring pleasure here and now.

Meaning in life is one of the most investigated variables related to SWB. Alike the results in current study, plenty of other investigations have shown that succeeding in finding meaning in life promotes psychological well-being (Steger et. al. 2006, 2008, 2011; Lazzari 2000; Rathi \& Rastogi, 2007; Mulders, 2011). It is understandable because eudemonic view of well-being stresses the importance of both pleasure and meaning in life. In other words, pursuing meaningful and pleasurable activities can significantly raise one's levels of well-being (Ben-Shahar, 2007).

Fruitful ground provided by pleasant memories of the past give potential sources for meaning in life. Past investigations have revealed that most contributing source of meaning in life among adolescents is their relationship with friends, partners and family. (Steger, et al., 2011; Mulders, 2011). Having in mind that PP orientation involves warm personal interactions as most dominant characteristic, it is clear why PP and PML are in significant positive correlation. Besides pleasant past experiences, meaning can be drawn from joyful moments on daily bases, too. Mulders (2011) suggests that post modernist youths meet a new challenge in a society with diverse orientations and are provided with more freedom and autonomy than generations before. As a result young people refuse to adopt an ideological framework, thus orienting toward more mundane, hedonistic ideas about meaning in life. As the author hypothesized, almost half of the adolescents participated in his study, mentioned pleasure as provider of meaning in life.

Significant correlations between SML and TP factors obtained in this study are consistent with those reported in similar ones. After analyzing several researches in this field, Steger et.al. (2008) concluded that SML might exemplify an inability to let go of painful past experiences (PN). In one previous study (Steger et.al., 2006), it was revealed that SML is in strong positive relation with neuroticism, depression and negative emotions, which is congruent with the unpleasant psychological states of individuals with PN focus. Having no stable ground for meaning in life derived from the meaningful past events, it appears that adolescents are stimulated to search for meaning in their future goals. With the focus on future time perspective, they make efforts to establish significance and purpose of their lives.

Although it could be easily assumed that PP is the essential time perspective for the individual's well-being and therefore developing it is the best one could do, Boniwell (2005) warns about its drawbacks and bad consequences of every excessive orientation. She further developed Zimbardo \& Boyd's model of ideal time perspective, suggesting that balanced time perspective is optimal for human functioning (Boniwell \& Zimbardo, 2004). According to the model, individuals with BTP profile show moderate to high scores on PP, F and PH and low scores (below 33 percentile) on PN and PF. 
In our sample, only 6 out of 81 participant (7.4\%) performed balanced TP profile, which means that flexibility and "switch-ability", as essential components of balanced TP, are not common for Macedonian undergraduate female students. Having in mind that according to previous findings BTP is hard to achieve (Boniwell, 2005, Drake et al., 2008) we can conclude that this is not exclusively the case in the current study.

This study found that the most prevalent temporal frame profile constitute individuals with moderate to high scores in all five TP factors. Compared with an ideal BTP profile (http://www.thetimeparadox.com), shown in Figure 1, it is evident that they achieved higher scores in the risk factors of $\mathrm{PF}$ and $\mathrm{PN}$, while $\mathrm{F}$ is not quite remarkable orientation. This image is characteristic for the developing countries, such as Republic of Macedonia, where poverty and unemployment are common features of the society. These conditions do not offer optimistic expectations for young people, so they believe that future is uninfluenced by their individual actions, but it is controlled by external factors. Also, facing the negative consequences of long-lasting transitional period in the country during their childhood, they could have painful memories and aversive attitude toward past.

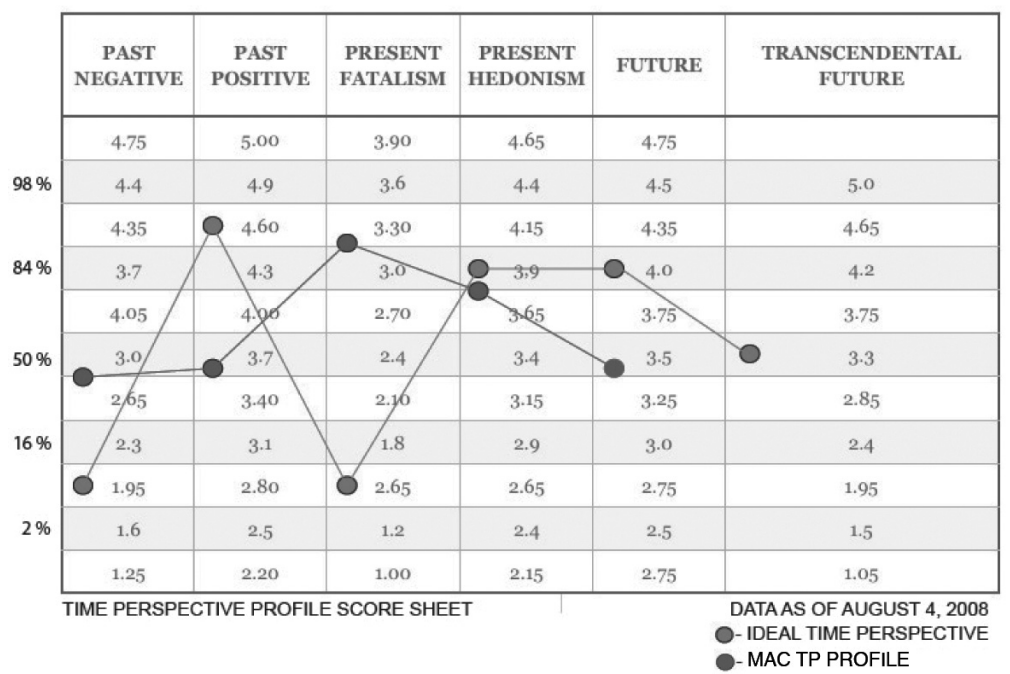

Figure 1. Comparison of ideal balanced time perspective profile and Macedonian sample time perspective profile.

Note. Ideal ??? ??? were retrieved from www.thetimeagnadox.com

Finally, in order to determine to what extent meaning in life and TP factors predict subjective well-being, multiple regression analysis method was used. For that purpose, method Forward was chosen, with .05 probability of $\mathrm{F}$ to enter.

Table 2 shows obtained coefficient of determination, while coefficients of regression models for SWB are presented in Table 3. 
Table 2 - Multiple Regression Analyses Predicting Subjective Well-Being

from Time Perspective Factors and Meaning in Life Dimensions

\begin{tabular}{|l|c|c|c|c|c|c|c|c|}
\hline \multicolumn{1}{|c|}{ Model } & $\mathrm{R}$ & $\mathrm{R}^{2}$ & Adj. $\mathrm{R}^{2}$ & $\mathrm{~F}$ & Sig. F & $\mathrm{R}^{2}$ Chg. & F Chg & $\mathrm{p}$ \\
\hline $\begin{array}{l}\text { 1. PN } \\
\text { (Constant) }\end{array}$ & .391 & .153 & .142 & 14.281 & .000 & .153 & 14.281 & .000 \\
\hline $\begin{array}{l}\text { 2. PN } \\
\begin{array}{l}\text { PML } \\
\text { (Constant) }\end{array}\end{array}$ & .465 & .217 & .197 & 10.783 & .000 & .064 & 6.323 & .014 \\
\hline
\end{tabular}

Table 3 - Coefficients of Regression Models for Subjective Well-Being

\begin{tabular}{|c|c|c|c|c|}
\hline Model & B & SE & $\beta$ & $\mathrm{p}$ \\
\hline $\begin{array}{l}\text { 1. PN } \\
\text { (Constant) }\end{array}$ & $\begin{array}{r}-1.071 \\
3.001\end{array}$ & $\begin{array}{l}.283 \\
.822\end{array}$ & -.391 & .000 \\
\hline $\begin{array}{l}\text { 2. PN } \\
\text { PML } \\
\text { (Constant) }\end{array}$ & $\begin{array}{l}-.963 \\
.080 \\
.596\end{array}$ & $\begin{array}{c}.278 \\
.032 \\
1.244\end{array}$ & $\begin{array}{l}-.352 \\
.255\end{array}$ & $\begin{array}{l}.001 \\
.014\end{array}$ \\
\hline
\end{tabular}

According to the findings, both Past Negative and Presence of Meaning in Life explain Subjective Well-being of adolescents at a significant and important level $\left(\mathrm{R}=.465, \mathrm{R}^{2}=.217\right.$, $\mathrm{F}=10.783$, $\mathrm{p}<.01)$. It was concluded in regression analysis that $\mathrm{PN}$ was significantly and negatively correlated with SWB $(\beta=-.352, p<.00)$, while PML was positively correlated with SWB on significant level $(\beta=.255, \mathrm{p}<.01)$. Thus, predictor variables explain significant part of the variance of subjective well-being: $14 \%$ of the variance is explained only with lack of Past Negative, while 20\% of variance is explained with both lack of Past Negative and Presence of Meaning in Life. This finding suggest that Macedonian female undergraduates who perceive themselves to have a purpose in life, in one hand, and do not hold negative views about their past, on the other hand, are more likely to develop positive judgment of their overall life.

\section{Conclusion}

In sum, the present study confirmed the findings from previous ones that subjective well-being has strong relation with presence of meaning in life among adolescents. It seems that the hedonic concept of well-being is insufficient for understanding why people are satisfied with their lives, and therefore it is necessary to broaden the concept in a more eudemonic manner. The same standpoint is promoted in Ben-Shahar's Hamburger model (2007, p.33): "A happy person enjoys positive emotions while perceiving life as purposeful... We need to gratify both Freud's will for pleasure and Frankl's will for meaning if we are to lead a fulfilling, happy life."

Also, it was found that Macedonian adolescents are more past oriented than oriented toward future goals, that could be interpreted with some cultural features mentioned in the discussion. Moreover, their subjective well-being mostly relays on benefits from their past positive experiences and lack of past negative ones. 
The results might suggest some practical implications that will help to increase adolescents' subjective well-being. Youths should be open to think about different sources of meaning that have personal significance for them. Also, relying on their past experiences, they should be stimulated on the process of meaning making driven not only from the pleasant past events, but also from the traumatic ones. According to Frankl (1977), meaning could be found not only in relations with the surrounding and occupation, but also in traumatic experiences. As a father of logotherapy, he suggests that through the process of logotharapy, it is possible to reveal meaning in the suffering by its acceptance and explaination with some higher goals. Finally, having more flexible attitude and developing switch-off ability in accordance to the external circumstances and personal needs, adolescents should learn how to balance their time perspectives.

\section{REFERENCES}

Ben-Shahar, T. (2007). Happier: Learn the Secrets to Daily Joy and Lasting Fulfillment. New York:McGrawHill.

Boniwell, I. \& Zimbardo, P. G. (2004), Balancing One’s Time Perspective in Pursuit of Optimal Functioning, in P. A. Linley and S. Joseph (eds) Positive Psychology in Practice, 165-178. Hoboken, NJ: Wiley.

Boniwell, I. (2005) Beyond time management: how the latest research on time perspective and perceived time use can assist clients with time-related concerns International Journal of Evidence Based Coaching and Mentoring Vol. 3, No. 2, 61-74.

CAIRns, D. (2010) Is searching for meaning in life associated with reduced subjective and psychological well-being? International Journal of Existential Psychology and Psychotherapy, Vol 3, No 1.

Diener, E., Diener, M. \& Diener, C. (1995). Factors predicting the well-being of nations. Journal of Personality and Social Psychology, 69, 653-663.

Diener, E, Lucas, R. E. \& Oishi, S. (2002) Subjective Well-Being: The Science of Happiness and Life Satisfaction, во Snyder, C. R, Lopez, S. J, Handbook of Positive Psychology, Oxford, University press.

De Lazzari, S. A., (2000), Emotional intelligence, meaning in life and psychological well-being: a comparison between early and late adolescence. A thesis submitted in partial fulfillment of the requirements for the degree of master of arts. The faculty of graduate studies graduate counseling psychology program. Trinity Western University.

Drake, L., Duncan, E., Sutherland, F., Abernethy, C. \& Henry, C., (2008), Time perspective and Correlates of Wellbeing, Time \& Society 17, 1, 47-61.

Durayappah, A. (2011). The 3P Model: A General Theory of Subjective Well-Being · Journal of Happiness Studies, Springer. Vol. 12, 4,681-716.

Eryilmaz, A. (2011). The Relationship Between Adolescents' Subjective Well-being and Positive Expectations Towards Future. Düşünen Adam The Journal of Psychiatry and Neurological Sciences, 24, 209-215.

FrankL, E. V. (1977), Man's Search for Meaning: An Introduction to Logotherapy, Simon and Schuster, New York.

Mulders, L. T. E. (2011), Meaning in life and its relationship to psychological well-being in adolescents, Master thesis submitted in Faculty of Social and Behavioural Theses, Utrecht University, Netherlands. 
Rathi, N. \& Rastogi, R. (2007) Meaning in life and psychological well-being in pre-adolescents and adolescents, Journal of the Indian Academy of Applied Psychology, Vol. 33, No.1, 31-38.

Reker, G. T., Peacock E. J. \& Wong. P. T. P. (1987), Meaning and Purpose in Life and WellBeing:A Life-Span Perspective, Journal of Gerontology, Vol.42, No.1, 44-49.

Steger, M. F., Frazier, P., Oishi, S., \& Kaler, M. (2006). The Meaning in Life Questionnaire: Assessing the presence of and search for meaning in life. Journal of Counseling Psychology, 53, 80-93.

Steger, M. F., Kashdan, T. B., Sullivan, B. A. and Lorentz D., (2008) Understanding the Search for Meaning in Life: Personality, Cognitive Style, and the Dynamic Between Seeking and Experiencing Meaning, Journal of Personality, 76, 199-228.

Steger, M. F. (2009). Meaning in life. In Lopez, S. J. (Ed.). Encyclopedia of positive psychology. (Vol.1). Chichester: Wiley-Blackwell.

Steger, M. F., Oishi, S., \& Kashdan, T. B. (2009). Meaning in life across the life span: Levels and correlates of meaning in life from emerging adulthood to older adulthood. Journal of Positive Psychology, 4:1, 43-52.

Steger, M. F., Oishi, S. \& Kesebir, S. (2011) Is a Life without Meaning Satisfying? The Moderating Role of the Search for Meaning in Satisfaction with Life Judgments, Journal of Positive Psychology, 6, 173-180.

Спасовски, О. (2009). Однос на субјективната добросостојба со базичните психолошки потреби, животните цели и со себеценењето. Необјавен докторски труд, Универзитет “Св Кирил и Методиј”.

The Time Paradox (2010). Retrieved from http://www.thetimeparadox.com

Veenhoven. R.. Average happiness in 149 nations 2000-2009. World Database of Happiness. Rank report Average Happiness. Internet: worlddatabaseofhappiness.eur.nl

Zimbardo, P. G. \& Boyd, J. N. (1999), Putting Time in Perspective: A Valid, Reliable Individualdifference Metric, Journal of Personality and Social Psychology 77, 1271-1288. 